\title{
Gender and Age as Determinants of Expected Rate of Return on Human Capital ${ }^{1}$
}

\author{
Bartosz Kurek², Ireneusz Górowski ${ }^{3}$
}

Submitted: 12.07.2020. Accepted: 25.10.2020

\section{Abstract}

Purpose: The aim of the article is to examine the selected determinants of the expected rate of return on human capital.

Methodology: We conducted an anonymous survey of expected salaries among the Accounting and Controlling students at the Cracow University of Economics, which provided a unique setting for the analysis. On the basis of collected data for the cost of living and the cost of professional education for every participant, we used the human capital model developed by Dobija to compute the perceived level of the human capital of each individual. Then, we compared the expected salaries with the perceived levels of human capital and computed expected rates of return on human capital. The following research methods are used: literature review, statistical tests, econometric modeling.

Findings: On the sample of 754 respondents, we found that male students expect a higher rate of return on their human capital than female students, while older students expect a lower rate of return on human capital than younger students.

Research limitations: Only one field of study was used to measure the determinants of the expected rate of return on human capital.

Originality: We contribute to the salary expectations and human capital literature by identifying a significant gender salary expectations gap that holds even after considering individually assessed costs of living and professional education. Our findings are consistent with the well-known observation that women tend to expect lower salaries than men.

Keywords: salary expectations, gender, tertiary education, human capital, return on human capital.

JEL: E24, J24.

The publication was financed from the subsidy granted to the Cracow University of Economics.

2 Cracow University of Economics, College of Management Sciences and Quality, Institute of Management, Department of Accounting, Rakowicka 27, 31-510 Cracow, Poland, http://orcid.org/0000-0002-8554-2874; e-mail: kurekb@uek.krakow.pl.

3 Cracow University of Economics, College of Management Sciences and Quality, Institute of Management, Department of Accounting, Rakowicka 27, 31-510 Cracow, Poland, http://orcid.org/0000-0002-2866-7857; e-mail: gorowski@uek.krakow.pl. 


\section{Introduction}

There are many competing approaches to the concept of human capital and its measurement (United Nations Economic Commission for Europe, 2016). Among the most popular approaches to measuring human capital is the cost-based approach. According to this approach, human capital can be calculated as a value resulting from past monetary outlays, which come from the individual, the family, employers, and governments. Most research in the field concentrates on the measurement of the stock of human capital in a macroeconomic perspective, e.g. Schultz (1961), Kendric (1976), and Eisner (1980). In this article, we address an original, competing "cost-based" model of human capital that was invented by M. Dobija. The major advantage of the model is the ability to compute the human capital of an individual person.

The proposed human capital model was originally described in Dobija (1998; 2000), and Dobija and Dobija (2005), and is widely discussed in literature, e.g. Cieślak and Dobija (2007), Hołda and Renkas (2015), Jędrzejczyk (2009), Kozioł (2010, 2011), Kozioł and Mikos (2019), Renkas (2012a; 2012b; 2013; 2014; 2018), and Stańdo-Górowska (2014).

Broadly speaking, the proposed human capital model assumes that capital is an abstract ability to perform labor that is embodied in assets, including human assets (cf. Dobija and Dobija, 2003; Dobija, 2007; 2010; 2014; 2016). As a result of this conjecture, human capital is a measurable notion, and its concentration in a particular asset (i.e. value of an asset) is expressed in monetary units. The measurement procedure is analogous to the measurement of the cost of production in financial accounting. ${ }^{4}$ The human capital model developed by Dobija uses the capitalized cost of living, the capitalized cost of professional education, and the experience factor. The minimum fair rate of return on human capital equals $8 \%$ per year and is known in the model as the economic constant of potential growth. This constant is also used to determine theoretical minimum fair wages in economies (e.g. in Poland or in Ukraine). So far, none of the researchers analyzed the determinants of the expected rate of return on human capital, ${ }^{5}$ which - contrary to the economic constant of potential growth - is the empirically observed number specific to each individual. The knowledge of these determinants would improve the understanding of gender salary expectations gap. We believe that such information could reduce the risk of gender and age self-discrim-

\footnotetext{
4 The financial accounting measurement of cost of production is explained in IAS 2 Inventories.

5 Renkas (2013) interviewed 135 job seekers in Ukraine in October 2010 and sought an association between the expected wage, age, and years of education.
} 
ination that results from the perceptions that employees have about their individual situation in the labor market.

The aim of the article is to examine the selected determinants of the expected rate of return on human capital. We investigate the determinants that are beyond respondents' control, such as gender and age, as these factors are of interest in the literature on salary expectations. We were especially inspired by existing research that links gender wage gap with human capital models, especially the one devised by Becker (1993), Pierce-Brown (1998), and Polachek (2004). These authors explain the differences in wages between men and women mainly by the personal lifetime voluntary choices. Our contribution comes to the empirical verification of whether these differences hold in the students' salary expectations, after controlling factors beyond voluntary choices (gender and age).

In October 2019, we conducted an anonymous survey among students enrolled in the Accounting and Controlling program at the Cracow University of Economics, and we received 754 questionnaires containing all the relevant data. With the use of Dobija (1998; 2000) and Dobija and Dobija (2005) human capital model and the application of individual data provided by each respondent (the cost of living and the cost of professional education), we computed the perceived level of human capital for each individual. Furthermore, we used information on expected salaries provided by each respondent to individually compute the expected rate of return on human capital for graduates of bachelor and master in the Accounting and Controlling program, with and without professional experience. We used gender and age as factors beyond respondents' control, contrary to their expectations. Gender and age are objective, while expectations are subjective. We built linear models in which subjective measures - rates of return on human capital - were dependent variables, while objective measures - gender and age - were independent variables.

The following research methods were used: literature review, statistical tests, and econometric modeling. We estimated econometric models by OLS, and we used Huber/ White robust standard errors to assess the statistical significance of each parameter. We used Stata/IC 14.1 for testing econometric models and for other statistical tests (Shapiro-Wilk W test, Wilcoxon signed-rank test, two-sample Wilcoxon rank-sum test, RESET test), along with Microsoft Office Excel 2013 for initial data filtering and descriptive statistics.

The article is organized as follows. Section 1 introduces the research problem, while section 2 explains the research methodology and states research hypotheses, and describes 
the conducted survey. Section 3 presents data. Section 4 describes empirical findings. Section 5 concludes and provides our recommendations for further research. The list of references follows the last section.

\section{Research Hypotheses and Research Methodology}

\section{Dobija Human Capital Model and Minimum Fair Wage}

The human capital model by Dobija $(1998,2000)$ and Dobija and Dobija (2005, p. 30-34) is a cost-based approach. Equation 1 presents the formula for the measurement of the individual level of human capital $\mathrm{H}(\mathrm{T})$ :

$$
H(T)=(K+E) \times[1+Q(T)]
$$

in which:

$\mathrm{H}(\mathrm{T})$ - the individual level of human capital,

$\mathrm{K}$ - capitalized cost of living,

$\mathrm{E}$ - capitalized cost of professional education,

$\mathrm{Q}(\mathrm{T})$ - experience factor,

$\mathrm{T}$ - years of professional experience.

Only justified living and educational expenses at the minimum level are used in the valuation of human capital, which stems from the least action principle. Justified living expenses refer to expenses required to form a healthy individual; i.e. these expenses represent the average of the minimum values in a particular country. Justified educational expenses relate to expenses required to gain professional education at a conventional level; i.e. these expenses may be different for various types of qualifications.

In the case of living and educational expenses, we used capitalized values. Therefore, in the accounting notation, the terms "cost of living" and "cost of professional education" are more appropriate than expenses. These costs are incurred over many years and, therefore, we should recognize the time value of money. Yearly or continuous capitalization may be used (cf. Dobija and Dobija, 2005; Kozioł and Mikos, 2019). Equations 2 and 3 present the formulas for the capitalized cost of living $\mathrm{K}$ and the capitalized cost of professional education $\mathrm{E}$ in the case of yearly capitalization: 


$$
\begin{aligned}
& K=k \times 12 \times \frac{(1+p)^{t}-1}{p} \\
& E=e \times 12 \times \frac{(1+p)^{t}-1}{p}
\end{aligned}
$$

in which:

$\mathrm{K}$ - capitalized cost of living,

$\mathrm{k}$ - monthly cost of living,

$\mathrm{p}$ - economic constant of potential growth (in the model assumed as $8 \%$ annually), ${ }^{6}$

$\mathrm{t}$ - in formula for $\mathrm{K}$ - years from birth till graduation (without gap years),

$\mathrm{E}$ - capitalized cost of professional education,

e - monthly cost of professional education,

$\mathrm{t}$ - in formula for $\mathrm{E}$ - years of professional education.

The experience factor $\mathrm{Q}(\mathrm{T})$ is calculated according to equation 4 :

$$
Q(T)=1-T^{\frac{\ln (1-w)}{\ln 2}}
$$

in which:

$\mathrm{Q}(\mathrm{T})$ - the experience factor,

$\mathrm{T}$ - years of professional experience,

$\mathrm{w}$ - learning rate.

Theoretical minimum fair wage/salary is calculated as a fair rate of return of $8 \%$ - the economic constant of potential growth used in the model - from the human capital, as shown in equation 5 :

$$
W=H(T) \times p
$$

in which:

$\mathrm{W}$ - theoretical minimum fair wage/salary,

$\mathrm{H}(\mathrm{T})$ - the individual level of human capital,

$\mathrm{p}$ - economic constant of potential growth.

\footnotetext{
6 An economic constant of potential growth might be estimated through the empirical analysis of a stock market in a developed economy. Two most common possibilities to approximate the number are to compute the long-term 1) arithmetic average risk premium and 2) arithmetic average return on assets of listed companies (calculated from annual financial statements). Research results (Kurek, 2011) confirm that the arithmetic average return on assets (period 1986-2005, companies constituting S\&P's 1500 index) is close to $8 \%$ and equals $8.57 \%$. Database by A. Damodaran (2020) shows that an average arithmetic risk premium (period 1928-2019, S\&P's 500 stocks minus T-bills) is close to $8 \%$ and equals $8.18 \%$. Although both numbers are highly stable, we should mention that the economic constant of potential growth might be affected by the changes in economic, political, and social environment (we thank the reviewer for this comment).
} 
According to the human capital model developed by Dobija, the theoretical minimum fair ${ }^{7}$ wage/salary is the total cost borne by the employer. In the case of Poland, net salary equals around $65,17 \%$ of the total cost borne by the employer, if the employee is below 26 years old. The remaining $34,83 \%$ consists of taxes, mandatory health, retirement, and accident insurance.

The minimum fair compensation calculated with the use of the economic constant of potential growth counterbalances the average natural dispersion of capital, which manifests itself through measurable risk. Therefore, the minimum fair wage/salary should enable an employer to keep the potential level of human capital constant. The further increase in the potential level of human capital may only result from professional education, professional experience, and the existence of creativity capital. ${ }^{8}$

\section{Perceived Level of Human Capital and the Expected Rate of Return on Human Capital}

In the Dobija human capital model, minimum values for the monthly cost of living and the monthly cost of professional education are used to calculate theoretical fair minimum wage/salary. Current values are used to remove the effect of inflation. In the model, the monthly cost of living is determined as the current social minimum in a family of four that consists of two adults and two children. In the second quarter of 2019, the cost equaled 977.13 PLN (IPISS, access date 1.11.2020). The reason for using minimum values is to avoid the inclusion of excess unreasonable spending on living in the calculation of the fair wage/salary. Least action principle is applied as there is no reason to recover a higher than the minimum cost of living.

However, many have different views about the required minimum cost of living and the cost of professional education. We believe that people with a greater perceived minimum cost of living and cost of professional education will demand a greater minimum level of wages/salaries in order to recover these expenses. However, the demands of various groups and individuals differ, which results from such factors as the current situation in the labor market or the level of self-esteem. Therefore, controlling for individually perceived levels of the minimum cost of living and the cost

\footnotetext{
7 The human capital model developed by Dobija is deeply rooted in accounting theory. Therefore, the term "fair" refers to economically fair values, which may not necessarily be socially fair.

8 The human capital model developed by Dobija enables us to determine the minimum fair wage/salary and by no means suggests that an employee should receive only this amount. Higher salaries are justified if a person has creativity capital (cf. Dobija, 2005; Kozioł, 2010; Renkas, 2017) and if a company has profits that can be shared with employees through bonuses (cf. Dobija, 2004, p. 39-40).
} 
of professional education is necessary to investigate which groups of people demand different rates of return on their human capital.

\section{Research Hypotheses Development}

Major and Konar (1984, pp. 787-788) notice that in the USA the difference in salary expectations between men and women increases over the career span: it is $16.5 \%$ at career entry compared to $46 \%$ at career peek. Similarly, Schweitzer, Lyons, Kuron, and Ng (2014, p. 404) find in Canada that young women not only have lower initial and peak salary expectations than young men but also lower perceptions of a fair wage. Chevalier (2007, p. 840) analyzes the gender wage gap among UK graduates three years after they leave university so as to find a raw wage gap of $12.6 \%$. Manning and Swaffield (2008) investigate the growth of the gender wage gap in early career in the UK to find that it may be partly explained by human capital factors. Pierce-Brown's (1998) research findings confirm that there is a large salary differential between the genders within professionally qualified accountants in the UK. Moreover, they show that the salary gap cannot be explained on the ground of women's lower productivity as the phenomenon has a more social than the economic background.

In some occupations, one may observe a higher share of female workers as compared to male workers. Czarniawska (2008, p. 45) claims that the accounting profession is perceived in Poland as a feminine job, ${ }^{9}$ although the reasons for this status quo remain unidentified. Kabalski and Szwajcar (2015, p. 85) investigate the feminization of accounting studies in Poland and claim that it results from the existing stereotype that accounting is viewed as a women's occupation. Masztalerz (2018, p. 326) confirms the quantitative dominance of women in Polish accounting and notices inequalities between genders in the structure of salaries, scientific degrees, and professional levels. Meanwhile, Piosik, Strojek-Filus, Sulik-Górecka, and Szewieczek (2019) prove that accounting professionals in Poland are satisfied with their job and that there is no significant difference between genders in that matter. However, they demonstrate that younger accounting professionals are more frequently satisfied with their profession compared to their older colleagues.

Inequality in the gender structure of accounting students - which manifests itself in the general feminization of the accounting profession in Poland ${ }^{10}$ - has much deeper

9 Positions in the broadly understood accounting industry significantly differ among each other and may require various skills and different levels of knowledge (e.g. bookkeeper, accountant, auditor, CF0, accounting professor).

10 Interestingly, the feminization of the accounting profession in Poland appears in sharp contrast with Japan: Komori (2008, p. 515) reports that the accounting profession in Japan is dominated by men to almost $90 \%$. At the same time, women have a significant influence on the 
and more significant implications. Positions in the lower hierarchy level are generally occupied by women. On the other hand, positions in the higher hierarchy level are generally occupied by men (cf. Kornberger, Carter, and Ross-Smith, 2010; Lupu, 2012). One of the explanations for this phenomenon is the perception of a glass ceiling in the accounting profession (cf. Cohen, Dalton, Holder-Webb, and McMillan, 2020). Din, Cheng, and Nazneen (2018, p. 1513) notice that "gender segregation narrows women's opportunities for mobility in the higher echelons of accounting firms." Jeny and Santacreu-Vasut (2017, p. 8) notice the low percentage of women - between $4 \%$ and $22 \%$ - on the global board in Big Four companies (Deloitte, E\&Y, KPMG, PwC). In numerical terms, there are significantly more lower hierarchy jobs than higher hierarchy jobs, hence the feminization of the accounting profession in Poland on a general level. According to the gender diversity report by AFECA (2016, pp. 31-33), the percentage of women in accountancy in Poland is at the level of $64 \%$, compared to as low as $15 \%$ in Switzerland and as high as $77.9 \%$ in Romania. For other countries in the region, the percentage of women in accountancy is at the level of 35.2\% (Germany), $40 \%$ (Austria), 48\% (Czech Republic), and 70\% (Hungary).

According to the human capital model developed by Dobija, the minimum economically fair wage/salary does not differ between the genders, as it is based on the justified cost of living, professional education, professional experience, and the economic constant of potential growth. Moreover, the minimum economically fair wage/salary does not depend on the age of an employee (holding education and years of professional experience fixed). Nevertheless, our previous research shows that women expect lower salaries than men, older students expect lower salaries than younger students (Kurek and Górowski, 2020a), and the expected rate of return on human capital varies for different types of graduates: bachelor, master, with and without professional experience (Kurek and Górowski, 2020b). Hence, we may believe that the factors of gender and age might be associated with the expected rate of return on human capital, although the Dobija human capital model does not discriminate against gender and age. Therefore, our research hypotheses assume the following form:

H1: Gender is associated with the expected rate of return on human capital.

H2: Age is associated with the expected rate of return on human capital.

Below, we operationalize these research hypotheses with econometric models. Thus, Table 1 defines variables, while Table 2 presents the econometric models. 


\section{Table 1. Definitions of variables}

\begin{tabular}{|c|c|}
\hline Variable & Description \\
\hline Exp. RoHC B/NE & $\begin{array}{l}\text { Nonnegative continuous variable - expected rate of return on human capital } \\
\text { for the graduate who completed Accounting and Controlling bachelor studies } \\
\text { and does not have any professional experience, given the respondent's expected } \\
\text { cost of living and cost of professional education (in \%). }\end{array}$ \\
\hline Exp. RoHC B/E & $\begin{array}{l}\text { Nonnegative continuous variable - expected rate of return on human capital } \\
\text { for the graduate who completed Accounting and Controlling bachelor studies } \\
\text { and has three years of professional experience, given the respondent's expected } \\
\text { cost of living and cost of professional education (in \%). }\end{array}$ \\
\hline Exp. RoHC M/NE & $\begin{array}{l}\text { Nonnegative continuous variable - expected rate of return on human capital } \\
\text { for the graduate who completed Accounting and Controlling bachelor and master } \\
\text { studies and does not have any professional experience, given the respondent's } \\
\text { expected cost of living and cost of professional education (in \%). }\end{array}$ \\
\hline Exp. RoHC M/E & $\begin{array}{l}\text { Nonnegative continuous variable - expected rate of return on human capital } \\
\text { for the graduate who completed Accounting and Controlling bachelor and master } \\
\text { studies and has three years of professional experience, given the respondent's } \\
\text { expected cost of living and cost of professional education (in \%). }\end{array}$ \\
\hline Gender & Dichotomous variable ( 1 - male, 0 - female). \\
\hline Age & Nonnegative discrete variable - age (in years). \\
\hline
\end{tabular}

Expected rate of return on human capital is calculated as Exp. RoHC $=W / H(T)$, which is the rearrangement of the Equation 5.

Source: own elaboration.

\section{Table 2. Econometric models}

\begin{tabular}{|l|c|}
\hline Model 1 & Exp.RoHC B $/ N E=\beta_{0}+\beta_{1}$ Gender $+\beta_{2}$ Age $+\varepsilon$ \\
\hline Model 2 & Exp.RoHC $B / E=\beta_{0}+\beta_{1}$ Gender $+\beta_{2}$ Age $+\varepsilon$ \\
\hline Model 3 & Exp.RoHC $M / N E=\beta_{0}+\beta_{1}$ Gender $+\beta_{2}$ Age $+\varepsilon$ \\
\hline Model 4 & Exp.RoHC $M / E=\beta_{0}+\beta_{1}$ Gender $+\beta_{2}$ Age $+\varepsilon$ \\
\hline
\end{tabular}

Source: own deliberations. 


\section{Institutional Setting of the Survey and the Calculation Method of the Rate of Return on Human Capital}

We use a unique setting for the analysis. First, Poland is one of the top five preferred locations for new or relocated shared services centers (Deloitte Development, 2019, p. 22). Second, there is a deficit of employees in Poland (including the Lesser Poland Voivodeship, with Krakow as the major city) in the area of accounting and bookkeeping (Wojewódzki Urząd Pracy w Krakowie 2018, pp. 19, 24, 30). Third, Dębkowska, Kłosiewicz-Górecka, Szymańska, Ważniewski, and Zybertowicz (2019, p. 8) inform that there are 21 universities in Krakow ${ }^{11}$ and more than 140 thousand students enrolled in various programs. According to the same report (Dębkowska et al., 2019, p. 16), Krakow was the fifth city in Europe in terms of the number of students (Eurostat data for Krakow from 2014 showed more than 180 thousand students). The Cracow University of Economics is the largest business school in Krakow, which offers various programs for bachelor, master, and doctoral students studying full - or part-time.

Taking the above into consideration, we may expect that salary expectations of accounting and controlling students in Krakow are not biased by a lack of occupational perspectives. Furthermore, we may believe that students in Krakow consciously selected the university and the field of their study.

In order to obtain data for the analysis in October 2019, we conducted an anonymous survey among students enrolled in the Accounting and Controlling program at the Cracow University of Economics. As of October 1, 2019, there were 1432 students enrolled in this program. We distributed 780 questionnaires among students present during lectures, which covered $54.47 \%$ of the population. Out of these questionnaires, 754 contained all data relevant for the analysis, which covered $52.65 \%$ of the population.

Students were asked to provide information on the minimum net salary for full-time employment that would be adequate to the educational background and professional experience of the four kinds of graduates: 1) a graduate with a bachelor's degree in Accounting and Controlling without any professional experience in accounting, controlling, or finance, 2) a graduate with a bachelor's degree in Accounting and Controlling with three years of professional experience in accounting, controlling, or finance, 3) a graduate with a master's degree in Accounting and Controlling without any professional experience in accounting, controlling, or finance, 4) a graduate with a master's

11 Krakow is the second largest city in Poland, following the Polish capital of Warsaw. Krakow is also one of the oldest Polish cities and it was the Polish capital until the end of eighteenth century. 
degree in Accounting and Controlling with three years of professional experience in accounting, controlling, or finance. Students were also asked to assess their cost of living and the cost of professional education. Furthermore, students were asked to provide several respondent's characteristics, such as age and gender.

We calculate the expected rate of return on human capital as the ratio of the total cost borne by the employer to the level of human capital. Each respondent provided information on expected net salary in four categories of graduates. These were converted into the total cost borne by the employer. Each respondent provided information on the perceived cost of living and the perceived cost of professional education. These were used to calculate the level of human capital in each four categories of graduates, as presented in Table 3.

Table 3. Assumptions for the calculation of human capital

\begin{tabular}{|l|c|c|c|c|}
\hline \multicolumn{1}{|c|}{ Human capital } & B/NE & B/E & M/NE & M/E \\
\hline $\begin{array}{l}\text { Data for cost of living and cost } \\
\text { of professional education }\end{array}$ & $\begin{array}{c}\text { Provided } \\
\text { by respondents }\end{array}$ & $\begin{array}{c}\text { Provided } \\
\text { by respondents }\end{array}$ & $\begin{array}{c}\text { Provided } \\
\text { by respondents }\end{array}$ & $\begin{array}{c}\text { Provided } \\
\text { by respondents }\end{array}$ \\
\hline $\begin{array}{l}\text { Assumed capitalization rate } \\
\text { for cost of living and } \\
\text { cost of professional education }\end{array}$ & $\begin{array}{c}8 \% \\
\text { per annum, } \\
\text { annual } \\
\text { capitalization }\end{array}$ & $\begin{array}{c}8 \% \\
\text { per annum, } \\
\text { annual } \\
\text { capitalization }\end{array}$ & $\begin{array}{c}8 \% \\
\text { per annum, } \\
\text { annual } \\
\text { capitalization }\end{array}$ & $\begin{array}{c}8 \% \\
\text { per annum, } \\
\text { annual } \\
\text { capitalization }\end{array}$ \\
\hline Assumed age of a graduate & 22 & 22 & 24 & 24 \\
\hline $\begin{array}{l}\text { Assumed years of professional } \\
\text { education }\end{array}$ & 3 & 3 & 5 & 5 \\
\hline $\begin{array}{l}\text { Assumed years of professional } \\
\text { experience }\end{array}$ & 0 & 3 & 0 & 3 \\
\hline Assumed learning rate & - & 0,1 & - & 0,1 \\
\hline
\end{tabular}

For example: a respondent provided the following data: $k=1200$ PLN, e $=400$ PLN, expected net salary for $B / E=$ 3800 PLN. The total cost that is borne by the employer equals to 5830 PLN $(3800 / 0,6518)$. The level of human capital for B/E is calculated using Equations 1, 2, 3 and 4:

$$
H(T)=\left(1200 \times 12 \times \frac{(1+0,08)^{22}-1}{0,08}+400 \times 12 \times \frac{(1+0,08)^{3}-1}{0,08}\right) \times\left[1+1-3^{\frac{\ln (1-0,1)}{\ln 2}}\right]=939373 \mathrm{PLN}
$$

The expected rate of return on human capital equals to Exp. RoHC B/E $=5830 \times 12 / 939373 \times 100[\%]=7,45 \%$. Source: own computations. 


\section{Data Description}

Table 4 presents descriptive statistics for the variables of interest. Table 5 displays the structure of the sample through the age and gender dimensions. Similarly to previous studies (Kabalski and Szwajcar, 2015; Masztalerz, 2018), our sample also reveals the feminization of the accounting profession in Poland. Table 6 shows the outcome of normality test for variables: none of the variables are normally distributed (Shapiro-Wilk W test). Therefore, the initial empirical analysis is based on medians.

Table 4. Descriptive statistics of variables

\begin{tabular}{|l|r|r|r|r|r|}
\hline Variable & Exp. RoHC B/NE & Exp. RoHC B/E & Exp. RoHC M/NE & Exp. RoHC M/E & Age \\
\hline Minimum & 0.43 & 0.50 & 0.41 & 0.51 & 18 \\
\hline Maximum & 29.11 & 29.44 & 26.57 & 29.48 & 40 \\
\hline Average & 7.15 & 8.58 & 7.59 & 9.14 & 22 \\
\hline Q1 & 5.13 & 6.05 & 5.20 & 6.19 & 20 \\
\hline Median & 6.48 & 7.72 & 6.84 & 8.01 & 21 \\
\hline Q3 & 8.40 & 10.20 & 9.06 & 11.25 & 23 \\
\hline$n$
\end{tabular}

Source: own computations.

Table 5. Structure of the sample

\begin{tabular}{|c|c|c|c|c|c|c|}
\hline \multirow[b]{3}{*}{ Age } & \multicolumn{3}{|c|}{ Number of observations } & \multicolumn{3}{|c|}{ Percentage of observations } \\
\hline & \multicolumn{2}{|c|}{ Gender } & \multirow[b]{2}{*}{ Total } & \multicolumn{2}{|c|}{ Gender } & \multirow[b]{2}{*}{ Total } \\
\hline & Male & Female & & Male & Female & \\
\hline 18 & 2 & 13 & 15 & $0.27 \%$ & $1.72 \%$ & $1.99 \%$ \\
\hline 19 & 15 & 83 & 98 & $1.99 \%$ & $11.01 \%$ & $13.00 \%$ \\
\hline 20 & 37 & 110 & 147 & $4.91 \%$ & $14.59 \%$ & $19.50 \%$ \\
\hline 21 & 29 & 113 & 142 & $3.85 \%$ & $14.99 \%$ & $18.83 \%$ \\
\hline 22 & 22 & 86 & 108 & $2.92 \%$ & $11.41 \%$ & $14.32 \%$ \\
\hline 23 & 17 & 123 & 140 & $2.25 \%$ & $16.31 \%$ & $18.57 \%$ \\
\hline 24 & 17 & 52 & 69 & $2.25 \%$ & $6.90 \%$ & $9.15 \%$ \\
\hline
\end{tabular}




\begin{tabular}{|c|r|r|r|r|r|r|}
\hline 25 & 2 & 13 & 15 & $0.27 \%$ & $1.72 \%$ & $1.99 \%$ \\
\hline Over 25 & 9 & 8 & 20 & $1.19 \%$ & $1.06 \%$ & $2.65 \%$ \\
\hline Total & 150 & 604 & 754 & $19.89 \%$ & $80.11 \%$ & $100.00 \%$ \\
\hline
\end{tabular}

Source: own computations.

Table 6. Shapiro-Wilk W test results for all variables

\begin{tabular}{|l|c|c|c|c|c|c|}
\hline Variable & $\begin{array}{c}\text { Exp. RoHC } \\
\text { B/NE }\end{array}$ & $\begin{array}{c}\text { Exp. RoHC } \\
\text { B/E }\end{array}$ & $\begin{array}{c}\text { Exp. RoHC } \\
\text { M/NE }\end{array}$ & $\begin{array}{c}\text { Exp. RoHC } \\
\text { M/E }\end{array}$ & Gender & Age \\
\hline p-value & $<0.0001$ & $<0.0001$ & $<0.0001$ & $<0.0001$ & 0.0002 & $<0.0001$ \\
\hline
\end{tabular}

Notes: Shapiro-Wilk W test was used to test normality of data (H0: a sample comes from a normally distributed population, $\mathrm{H1}$ : a sample does not come from a normally distributed population).

Source: own computations.

Table 7. Median differences for expected rates of return on human capital

Variable 1 less Variable 2

\section{Experience vs. No experience}

\begin{tabular}{l|l|l|}
\hline Exp. RoHC B/E less Exp. RoHC B/NE & 1.06 & $<0.0001$ \\
\hline Exp. RoHC M/E less Exp. RoHC M/NE & 0.98 & $<0.0001$
\end{tabular}

Master vs. Bachelor
Exp. RoHC M/NE less Exp. RoHC B/NE
0.13
$<0.0001$
Exp. RoHC M/E less Exp. RoHC B/E
0.21
$<0.0001$

\section{Bachelor experience vs. Master no experience}

Exp. RoHC B/E less Exp. RoHC M/NE

0.74

$<0.0001$

Notes: Wilcoxon signed-rank test was used to verify statistical significance of median differences (HO: median difference between pairs of observations is zero, $\mathrm{H} 1$ : median difference between pairs of observations is different from zero). Source: own computations.

The median expected rate of return on human capital is greater for a graduate with a master's degree compared to a graduate with a bachelor's degree, ceteris paribus. Similarly, the median rate of return on human capital is greater for a graduate with professional experience compared to a graduate without professional experience, ceteris paribus. Educational level increases the expected rate of return on total human capital. Similarly, professional experience increases the expected rate of return on total human capital. 
Interestingly, the median rate of return on human capital is greater for a graduate with a bachelor's degree and professional experience compared to a graduate with a master's degree and without professional experience. Corresponding outcomes apply to averages. Table 7 presents median differences between rates of return on human capital and the results of Wilcoxon signed-rank test. All results are highly statistically significant.

\section{Empirical Analysis}

Table 8 shows evidence on the gender salary expectations gap. The rate of return on human capital expected by males is significantly different than the rate of return on human capital expected by females (these results support $H 1$ ). The median rate of return on human capital in the group of male students is greater than the median rate of return on human capital in the group of female students, which applies to all types of graduates $(\mathrm{B} / \mathrm{NE}, \mathrm{B} / \mathrm{E}, \mathrm{M} / \mathrm{NE}, \mathrm{M} / \mathrm{E})$. All results are statistically significant, at least at the $5 \%$ level.

Table 8. Differences between median rates of return on human capital for male and female students

\section{Differences between genders for variables}

Exp. RoHC B/NE [Male]
- Exp. RoHC B/NE [Female]

Exp. RoHC B/E [Male]

- Exp. RoHC B/E [Female]

Exp. RoHC M/NE [Male]

- Exp. RoHC M/NE [Female]

Exp. RoHC M/E [Male]

- Exp. RoHC M/E [Female]

\section{Absolute difference between medians $\dagger$}

Relative difference between medians $\dagger$ (relative to females)

\section{p-value for absolute} difference

$$
8.58-7.65=\mathbf{0 . 9 4} * * * \quad 0.94 / 7.65=\mathbf{1 2 . 2 3} \% \quad 0.0038
$$

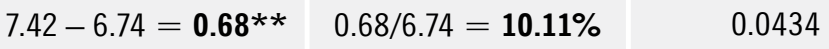

\begin{tabular}{l|l|l|l}
$8.69-7.85=\mathbf{0 . 8 4} * *$ & $0.84 / 7.85=\mathbf{1 0 . 7 0} \%$ & 0.0136
\end{tabular}

Notes: Two-sample Wilcoxon rank-sum (Mann-Whitney) test was used to verify whether male and female samples are from populations with the same distribution ( $\mathrm{HO}$ : two independent samples are from populations with the same distribution, $\mathrm{H1}$ : two independent samples are from populations with the same distribution); statistical significance: * statistically significant at $10 \%$, ** statistically significant at $5 \%, * * *$ statistically significant at $1 \%$; absolute difference between medians is expressed in percentage points, relative difference between medians is expressed in percent; †all differences are computed without rounding individual observations (only final value is rounded to two digits after a comma).

Source: own computations. 
Table 9 shows the results of the estimation. Gender is associated with the expected rate of return on human capital (H1 is confirmed). Holding age fixed, male students expect a higher rate of return on human capital by 1.07 percentage points $(\mathrm{B} / \mathrm{NE}), 1.44$ percentage points $(\mathrm{B} / \mathrm{E}), 0.87$ percentage points $(\mathrm{M} / \mathrm{NE}), 1.30$ percentage points $(\mathrm{M} / \mathrm{E})$. Age is associated with the expected rate of return on human capital (H2 is confirmed). Holding gender fixed, the increase of age by one year is associated with a decrease in the expected rate of return on human capital by 0.14 percentage points (B/NE), 0.12 percentage points (B/E), 0.24 percentage points (M/NE), and 0.27 percentage points $(\mathrm{M} / \mathrm{E})$.

Table 9. Econometric models - results of estimation

\begin{tabular}{|c|c|c|c|c|}
\hline Model & Model 1 & Model 2 & Model 3 & Model 4 \\
\hline Variable & $\begin{array}{l}\text { Dependent v. } \\
\text { Exp. RoHC B/NE }\end{array}$ & $\begin{array}{l}\text { Dependent v. } \\
\text { Exp. RoHC B/E }\end{array}$ & $\begin{array}{l}\text { Dependent v. } \\
\text { Exp. RoHC M/NE }\end{array}$ & $\begin{array}{l}\text { Dependent v. } \\
\text { Exp. RoHC M/E }\end{array}$ \\
\hline Gender & $\begin{array}{c}1.07 * * * \\
(0.31) \\
\text { p-value }=0.0007\end{array}$ & $\begin{array}{c}1.44 * * * \\
(0.42) \\
\text { p-value }=0.0007\end{array}$ & $\begin{array}{c}\mathbf{0 . 8 7} * * * \\
(0.33) \\
\text { p-value }=0.0083\end{array}$ & $\begin{array}{c}1.30 * * * \\
(0.44) \\
\text { p-value }=0.0031\end{array}$ \\
\hline Age & $\begin{array}{c}-\mathbf{0 . 1 4} * * * \\
(0.05) \\
\mathrm{p} \text {-value }=0.0043\end{array}$ & $\begin{array}{c}-\mathbf{0 . 1 2 *} \\
(0.06) \\
\text { p-value }=0.0529\end{array}$ & $\begin{array}{c}-\mathbf{0 . 2 4 * * *} \\
(0.05) \\
\text { p-value }<0.0001\end{array}$ & $\begin{array}{c}-\mathbf{0 . 2 7} * * * \\
(0.07) \\
\mathrm{p} \text {-value }=0.0001\end{array}$ \\
\hline Constant & $\begin{array}{c}9.92 * * * \\
(1.06) \\
\text { p-value }<0.0001\end{array}$ & $\begin{array}{c}10.93^{* * *} \\
(1.38) \\
\text { p-value }<0.0001\end{array}$ & $\begin{array}{c}12.57 * * * \\
(1.16) \\
\text { p-value }<0.0001\end{array}$ & $\begin{array}{c}14.67 * \star \star \\
(1.48) \\
\text { p-value }<0.0001\end{array}$ \\
\hline $\mathrm{n}$ & 754 & 754 & 754 & 754 \\
\hline $\mathrm{R}^{2}$ & 0.0275 & 0.0254 & 0.0345 & 0.0315 \\
\hline $\mathrm{F}$ & $\begin{aligned} F(2,751) & =9.65^{* * *} \\
p-\text { value } & =0.0001\end{aligned}$ & $\begin{aligned} \mathrm{F}(2,751) & =7.80 * * * \\
\mathrm{p}-\text { value } & =0.0004\end{aligned}$ & $\begin{array}{l}F(2,751)=13.83 \\
p \text {-value }<0.0001\end{array}$ & $\begin{array}{l}\mathrm{F}(2,751)=12.32 \\
\mathrm{p} \text {-value }<0.0001\end{array}$ \\
\hline Mean VIF & 1.00 & 1.00 & 1.00 & 1.00 \\
\hline RESET & $\begin{array}{c}F(3,748)=0.56 \\
p \text {-value }=0.6384\end{array}$ & $\begin{array}{c}F(3,748)=0.18 \\
p \text {-value }=0.9071\end{array}$ & $\begin{array}{c}F(3,748)=1.33 \\
p \text {-value }=0.2642\end{array}$ & $\begin{array}{c}F(3,748)=0.62 \\
p \text {-value }=0.6048\end{array}$ \\
\hline
\end{tabular}

Notes: for Independent variables and Constant rows the first number represents the estimated coefficient (the estimation was conducted with the OLS method) which is bolded if the parameter for the particular independent variable is statistically significant (*statistically significant at $10 \%, * *$ statistically significant at $5 \%$, ***statistically significant at $1 \%$ ), the second number shown in parentheses represents Huber/White robust standard errors and the third number represents $p$-value; $n$ is the number of observations; $R 2$ is the coefficient of determination; $F$ test ( $H 0$ : all variables are jointly insignificant, $\mathrm{H} 1$ : all variables are jointly significant), where the first number is the value of statistics $\mathrm{F}$, and the second number is the p-value; Mean VIF is the mean variance inflation factor; RESET is the Ramsey Regression Equation Specification Error Test (HO: model has no omitted variables, H1: model has omitted variables), where the first number is the value of statistics $F$, and the second number is the $p$-value.

Source: own computations. 


\section{Conclusions and Further Research Recommendations}

The human capital model proposed by Dobija $(1998 ; 2000)$ and Dobija and Dobija (2005) allows researchers to calculate fair minimum wage/salary for various groups of employees. Understood as the total cost borne by the employer, fair wage/salary equals the theoretical rate of $8 \%$ of accumulated human capital. This rate is defined in the model as the economic constant of potential growth.

Empirical observation shows that the expected rates of return on human capital vary for different groups of graduates. Our survey of 754 Accounting and Controlling students at the Cracow University of Economics shows that: 1) the median expected rate of return on human capital for a graduate with a bachelor's degree in Accounting and Controlling without any professional experience in accounting, controlling, or finance equals $6.48 \%$; 2 ) the median expected rate of return on human capital for a graduate with a bachelor's degree in Accounting and Controlling with three years of professional experience in accounting, controlling, or finance equals 7.72\%; 3) the median expected rate of return on human capital for a graduate with a master's degree in Accounting and Controlling without any professional experience in accounting, controlling, or finance equals $6.84 \%$; 4 ) the median expected rate of return on human capital for a graduate with a master's degree in Accounting and Controlling with three years of professional experience in accounting, controlling, or finance equals $8.01 \%$. The median expected rate of return on human capital for all types of graduates equals $7,28 \%$. The averages are slightly higher and reach the following values: 7.15\% (B/NE), $8.58 \%(\mathrm{~B} / \mathrm{E}), 7.59 \%(\mathrm{M} / \mathrm{NE}), 9.14 \%(\mathrm{M} / \mathrm{E})$, and $8.12 \%$ for all types of graduates. However, the averages are vulnerable to extreme observations.

We identified significant gender and age salary expectation gaps that manifest in different expected rates of return on human capital and exist even when one considers individually assessed costs of living and professional education. Therefore, both H1 and $\mathrm{H} 2$ are confirmed. Median expected returns on human capital are greater for men and in relative values range between $10.11 \%(\mathrm{M} / \mathrm{NE})$ and $13.39 \%(\mathrm{~B} / \mathrm{NE})$. There might be different reasons for such a situation, which requires further examination.

It is not surprising that master studies without professional experience are less valued by students than bachelor studies with professional experience. Three years of experience are - in the eyes of students - worth more than additional two years of theoretical studies. This may suggest that the expected rate of return from additional professional education (master level) is lower than the expected rate of return from professional experience (at least in the initial years). 
Students expect a higher rate of return on human capital for a master's degree holder than for a bachelor's degree holder; i.e. students not only expect a higher salary but also a higher rate of return. That corresponds to bank deposit terms: the longer the bank deposit, the higher the rate of return (in normal conditions).

Our previous research findings (Kurek and Górowski, 2020a) show that higher salaries were expected by male students and by younger students. The current research outcome provides a deeper understanding of this phenomenon. Now we also know that male students expect a higher rate of return on human capital, while older students expect a lower rate of return on human capital. The research findings take into account the levels of human capital perceived by each respondent individually. Therefore, the findings are robust to differently perceived levels of the cost of living and the cost of professional education.

As Heckert et al. (2002) suggest, one of the possible explanations is the prediction of lower salaries by women for themselves. In our opinion, this can be explained by the fact that women tend to occupy lower hierarchy level positions, whereas men tend to be appointed to higher hierarchy level positions. Furthermore, lower hierarchy jobs may become automated in the future (e.g. general ledger, invoicing), ${ }^{12}$ which currently is a trend in other industries. Since accounting students at the Cracow University of Economics are employed in international companies - Cracow is one of the big shared services centers in Europe - we believe that they are aware of that situation. Therefore, they incorporate the knowledge on the stratification of genders among various levels of accounting positions and associated levels of salaries and thus expect a return on human capital accordingly. Let us note that this point may be another limitation of our study. This change may cause significant, gloomy, and disturbing consequences for the accounting profession: the increasing inequality of salaries levels between men and women, which may, in turn, lead to the decrease in the overall level of salaries accompanied by the subsequent deterioration of the prestige of the accounting occupation.

At this point, further research questions arise that should be investigated in future research, such as why women expect a lower rate of return on human capital? It would be also worthwhile to investigate why older students expect a lower rate of return on human capital? Another possible extension would be to follow the study by Jerrim (2011) who compares expected salaries with actual ones in the same cohort. That is,

12 The application of Robotic Process Automation may have positive implications for the accounting profession. Once repetitive and manual tasks are automated, accountants may concentrate on more creative thinking and complex tasks; for implications of RPA in auditing, see Moffitt, Rozario, and Vasarhelyi (2018). 
it would be worthwhile to examine whether the same is applicable for expected and actual rates of return on human capital.

Furthermore, future research should concentrate on other determinants of the expected rate of return on human capital, such as respondents' grade point average, and respondents' additional qualifications. Future researchers should look at the socioeconomic background of respondents: their number of siblings, the education of parents, and average spending by the family. We believe that it may have a significant impact on the expected cost of living and the expected cost of education.

Last but not least, there are limitations to our analysis. The major one is the use of data from just one university in the large city. It would be beneficial to include data from smaller universities located in smaller cities, which is also our recommendation for future researchers.

\section{Acknowledgements}

We would like to thank the Associate Editor for constructive and insightful guidance for the improvement of our article's quality. We would also like to thank the anonymous reviewers for their valuable and meaningful remarks. Last but not least, we would like to thank M. Dobija for thoughtful academic consultations that greatly enhanced our work.

\section{References}

AFECA (2016). Gender Diversity in the European accountancy profession. An AFECA Study with the Support of FEE. Paris: Association des Femmes diplômées d'Expertise Comptable Administrateurs, https://www.accountancyeurope.eu/wp-content/uploads/Afeca_Gender-Diversity-in-the-European-Accountancy-Profession.pdf (18.10.2020).

Becker, G.S. (1993). Human Capital. A Theoretical and Empirical Analysis, with Special Reference to Education. 3rd Edition (first edition 1964). Chicago and London: The University of Chicago Press.

Chevalier, A. (2007). Education, Occupation and Career Expectations: Determinants of the Gender Pay Gap for UK Graduates. Oxford Bulletin of Economics and Statistics, 69(6), 819-842. https://doi.org/10.1111/j.1468-0084.2007.00483.x.

Cieślak, I. and Dobija, M. (2007). Teoretyczne podstawy rachunkowości kapitału ludzkiego. Zeszyty Naukowe Akademii Ekonomicznej w Krakowie, 735, 5-24.

Cohen, J.R., Dalton, D.W., Holder-Webb, L.L. and McMillan, J.J. (2020). An Analysis of Glass Ceiling Perceptions in the Accounting Profession. Journal of Business Ethics, 164, 17-38.

https://doi.org/10.1007/s10551-018-4054-4.

Czarniawska, B. (2008). Accounting and gender across times and places: An excursion into fiction. Accounting, Organizations and Society, 33(1), 33-47. https://doi.org/10.1016/j.aos.2006.09.006. 
Damodaran, A. (2020). http://people.stern.nyu.edu/adamodar/New_Home_Page/datacurrent.html (27.08.2020).

Dębkowska, K., Kłosiewicz-Górecka, U., Szymańska, A., Ważniewski, P. and Zybertowicz, K. (2019). Akademickość polskich miast, Polski Instytut Ekonomiczny,

http://pie.net.pl/wp-content/uploads/2019/06/PIE-Raport_Akademicko\%C5\%9B\%C4\%87.pdf (10.01.2020).

Deloitte Development (2019). Global Shared Services Survey Report (Executive Summary), 11th biennial edition. Deloitte,

https://www2.deloitte.com/content/dam/Deloitte/us/Documents/process-and-operations/2019-global-shared-services-survey-results.pdf (20.12.2020).

Din, N.U., Cheng, X. and Nazneen, S. (2018). Women's skills and career advancement: a review of gender (in)equality in an accounting workplace. Economic Research - Ekonomska Istraživanja, 3(1), 1512-1525. https://doi.org/10.1080/1331677X.2018.1496845.

Dobija, D. (2005). Metoda pomiaru kapitału kreatywności. Zeszyty Teoretyczne Rachunkowości, 26(82), 77-85.

Dobija, M. (1998). How to Place Human Resources into the Balance Sheet? Journal of Human Resource Costing \& Accounting, 3(1), 83-92. https://doi.org/10.1108/eb029044.

Dobija, M. (2000). Human Resource Costing and Accounting as a Determinant of Minimum Wage Theory. Zeszyty Naukowe Akademii Ekonomicznej w Krakowie, 553, 39-61.

Dobija, M. (2004). Zgodność płacy z wartością pracy jako zasada równowagi ekonomicznej. Nierówności Społeczne a Wzrost Gospodarczy, 4, 27-43.

Dobija, M. (2007). Abstract nature of capital and money. In: L.M. Cornwall (ed.), New Developments in Banking and Finance (pp. 89-114). New York, NY: Nova Science Publishers.

Dobija, M. (2010). Gospodarka jako gra o sumie niezerowej. Natura kapitału i zysku. In: M. Dobija (ed.), Teoria pomiaru kapitału i zysku (pp. 21-49). Kraków: Wydawnictwo Uniwersytetu Ekonomicznego w Krakowie.

Dobija, M. (2014). Kategoria kapitału i fundamentalne zasady kształtujące rzeczywistość ekonomiczną. In: M. Dobija (ed.), Teoria rachunkowości. Podstawa nauk ekonomicznych (pp. 15-45). Kraków: Wydawnictwo Uniwersytetu Ekonomicznego w Krakowie.

Dobija, M. (2016). Układ pojęć konstytuujących teorię rachunkowości w kontekście nauk ekonomicznych. Zeszyty Teoretyczne Rachunkowości, 89(145), 9-28, https://doi.org/10.5604/16414381.1218241.

Dobija, M. and Dobija, D. (2003). O naturze kapitału. Zeszyty Teoretyczne Rachunkowości, 17(73), $5-27$.

Dobija, M. and Dobija, D. (2005). Kapitał jako podstawowa kategoria ekonomii i rachunkowości. In: M. Dobija (ed.), Teoria rachunkowości w zarysie (pp. 11-42). Kraków: Wydawnictwo Akademii Ekonomicznej w Krakowie.

Eisner R. (1980). Capital gains and income: real changes in the value of capital in the United States, 1946-1977. In: D. Usher (ed.) The Measurement of Capital. Studies in Income and Wealth (pp. 175-346). Chicago: University of Chicago Press.

Heckert, T.M., Droste, H.E., Adams, P.J., Griffin, C.M., Roberts, L.L., Mueller, M.A., and Wallis, H.A. (2002). Gender differences in anticipated salary: Role of salary estimates for others, job characteristics, career paths, and job inputs. Sex roles, 47(3-4), 139-151. https://doi.org/10.1023/A:1021095005694.

Hołda, A. and Renkas, J. (2015). Fair wage and the size of pension contributions in the theory of human capital measurement. Актуальні проблеми економіки, 12, 302-311.

IAS \#2 Inventories, Commission Regulation (EC) No 1126/2008 of 3 November 2008 adopting certain international accounting standards in accordance with Regulation (EC) No 1606/2002 of the 
European Parliament and of the Council. Official Journal of the European Union, L320, https://eur-lex.europa.eu/legal-content/EN/TXT/PDF/?uri=CELEX:32008R1126\&from=EN (20.12.2019).

IPISS, Wysokość minimum socjalnego, https://www.ipiss.com.pl/?zaklady=minimum-socjalne, (11.01.2020).

Jeny, A. and Santacreu-Vasut, E. (2017). New avenues of research to explain the rarity of females at the top of the accountancy profession. Palgrave Communications, 3, 17011.

https://doi.org/10.1057/palcomms.201.

Jerrim, J. (2011). Do UK higher education students overestimate their starting salary? Fiscal Studies, 32(4), 483-509. https://doi.org/j.1475-5890.2011.00148.x.

Jędrzejczyk, M. (2009). Zastosowanie kursu walutowego do porównywania wynagrodzeń pracowników naukowych w Polsce i USA. Zeszyty Naukowe Uniwersytetu Szczecińskiego, 552, 177-188.

Kabalski, P. and Szwajcar, J. (2015). Feminizacja studiów w zakresie rachunkowości w Polsce - przyczyny i skutki. Zeszyty Teoretyczne Rachunkowości, 81(137), 85-106, https://doi.org/10.5604/16414381.1155233.

Kendrick, J.W. (1976). The Formation and Stock of Total Capital. New York: Columbia University Press.

Kirkham, L.M. and Loft, A. (1993). Gender and the construction of the professional accountant. Accounting, Organizations and Society, 18(6), 507-558. https://doi.org/10.1016/0361-3682(93)90002-N.

Komori, N. (2008). Towards the feminization of accounting practice. Lessons from the experiences of Japanese women in the accounting profession. Accounting, Auditing \& Accountability Journal, 21(4), 507-538, https://doi.org/10.1108/09513570810872905.

Kornberger, M., Carter, C. and Ross-Smith, A. (2010). Changing gender domination in a Big Four accounting firm: Flexibility, performance and client service in practice. Accounting, Organizations and Society, 35(8), 775-791. https://doi.org/10.1016/j.aos.2010.09.005.

Kozioł, W. (2010). Kształtowanie wynagrodzeń podstawowych nauczycieli akademickich na podstawie pomiaru kapitału ludzkiego i intelektualnego. Nierówności społeczne a wzrost gospodarczy, 16, 280-290.

Kozioł, W. (2011). Ekonomiczne aspekty procesu edukacji. Zeszyty Naukowe Małopolskiej Wyższej Szkoły Ekonomicznej w Tarnowie, 18(1), 185-194. https://doi.org/10.25944/znmwse.201 1.01.187196.

Kozioł, W. and Mikos, A. (2019). The measurement of human capital as an alternative method of job evaluation for purposes of remuneration. Central European Journal of Operations Research, https://doi.org/10.1007/s10100-019-00629-w.

Kurek, B. (2011). Hipoteza deterministycznej premii za ryzyko. Monografie: Prace doktorskie Nr 10. Kraków: Uniwersytet Ekonomiczny w Krakowie.

Kurek, B. and Górowski, I. (2020a). Determinants of salary expectations - A survey of Accounting and Controlling students, paper submitted to the conference: IV Ogólnopolska Konferencja Naukowa z cyklu Edukacja dla przedsiębiorczości na temat Internacjonalizacja szkolnictwa wyższego oraz edukacji dla przedsiębiorczości.

Kurek, B. and Górowski, I. (2020b). Expected Return on Human Capital - Pilot Survey among Accounting and Controlling Students. In: A. Jaki and B. Ziębicki (eds.), Knowledge - Economy - Society. External and Internal Determinants of Modern Business Management (pp. 73-82). Toruń: TNOIK Dom Organizatora.

Lupu, I. (2012). Approved routes and alternative paths: The construction of women's careers in large accounting firms. Evidence from the French Big Four. Critical Perspectives on Accounting, 23(4-5), 351-369. https://doi.org/10.1016/j.cpa.2012.01.003. 
Major, B. and Konar, E. (1984). An Investigation of Sex Differences in Pay Expectations and Their Possible Causes. The Academy of Management Journal, 27(4), 777-792.

https://doi.org/10.2307/255878.

Manning, A. and Swaffield, J. (2008). The gender gap in early-career wage growth. The Economic Journal, 118(530), 983-1024. https://doi.org/10.1111/j.1468-0297.2008.02158.x.

Masztalerz, M. (2018). Czy rachunkowość w Polsce jest kobietą. Prace Naukowe Uniwersytetu Ekonomicznego we Wrocławiu, 503, 326-335. https://doi.org 10.15611/pn.2018.503.28.

Moffitt, K.C., Rozario, A.M. and Vasarhelyi, M.A. (2018). Robotic Process Automation for Auditing. Journal of Emerging Technologies in Accounting, 15(1), 1-10. https://doi.org/10.2308/jeta-10589.

Pierce-Brown, R. (1998). An application of human capital theory to salary differentials in the accounting profession. Women in Management Review, 13(5), 192-200, https://doi.org:10.1108/09649429810221959.

Piosik, A., Strojek-Filus, M., Sulik-Górecka, A. and Szewieczek, A. (2019). Gender and Age as Determinants of Job Satisfaction in the Accounting Profession: Evidence from Poland. Sustainability, 11(11). https://doi.org/3090. 10.3390/su11113090.

Polachek, S.W. (2004). How the Human Capital Model Explains Why the Gender Wage Gap Narrowed, IZA Discussion Papers, No. 1102, Institute for the Study of Labor (IZA), Bonn, http://hdl.handle.net/10419/20337 (28.08.20).

Renkas, J. (2012a). An Analysis and Assessment of the Minimum Wage in the Economy of Ukraine on the Basis of the Human Capital Theory. In: A. Malina, R. Oczkowska and T. Rojek (eds.), Knowledge-Economy-Society. Dilemmas of the contemporary management (pp. 81-86). Cracow: Cracow University of Economics.

Renkas, J. (2012b). Empiryczny test modelu kapitału ludzkiego i minimalnych wynagrodzeń. Nierówności Społeczne a Wzrost Gospodarczy, 24, 180-191.

Renkas, J. (2013). Wage Expectations in Light of Human Capital Measurement Theory. Argumenta Oeconomica Cracoviensia, 9, 29-42. http://dx.doi.org/10.15678/AOC.2013.0902.

Renkas, J. (2014). Teoria pomiaru kapitału ludzkiego jako podstawa analizy wynagrodzeń $w$ gospodarce Ukrainy, PhD thesis, Uniwersytet Ekonomiczny w Krakowie, Kraków.

Renkas, J. (2017). Kapitał kreatywności - pomiar i wynagradzanie. Nierówności Społeczne a Wzrost Gospodarczy, 50, 413-426.

Renkas, J. (2018). Pomiar i sprawozdawczość kapitału ludzkiego w gospodarce Ukrainy, Wydawnictwo BREZA, Użgorod.

Schultz, T.W. (1961). Investment in Human Capital. American Economic Review, 51(1), 1-17.

Schweitzer, L., Lyons, S., Kuron, L.K.J. and Ng, E.S.W. (2014). The gender gap in pre-career salary expectations: a test of five explanations. Career Development International, 19(4), 404-425. http://dx.doi.org/10.1108/cdi-12-2013-0161.

Stańdo-Górowska, H. (2014). Oczekiwania płacowe studentów a model kapitału ludzkiego. Zeszyty Naukowe Uniwersytetu Ekonomicznego w Krakowie, 928(4), 51-59, http://dx.doi.org/10.15678/ZNUEK.2014.0928.0404.

United Nations Economic Commission for Europe (2016). Guide on Measuring Human Capital. Geneva: United Nations, https://unstats.un.org/unsd/nationalaccount/consultationDocs/HumanCapitalGuide.web.pdf (05.11.2019).

Wojewódzki Urząd Pracy w Krakowie (2018). Barometr zawodów 2019. Kraków: Wojewódzki Urząd Pracy. Obtained from:

https://barometrzawodow.pl/userfiles/Barometr/2019/raport_ogolnopolski_pl.pdf (05.11.2019). 